\title{
Waste Minimization Benefits and Obstacles for Solid Industrial Wastes in Malaysia
}

\author{
Shadi Kafi Mallak ${ }^{1}$, Mohd Bakri Ishak ${ }^{1,}$ Ahmad Fariz Mohamed ${ }^{2}$ \\ ${ }^{1}$ Department of Environmental Management, Faculty of Environmental studies, Universiti Putra Malaysia. \\ ${ }^{2}$ Institute for Environment and Development (LESTARI), Universiti Kebangsaan Malaysia
}

\begin{abstract}
Moving toward a sustainable industrial activity requires an effective waste management that is applicable and efficient for all different types of industrial wastes. Waste minimization as the most acceptable option in waste management hierarchy, has a significant contribution in minimizing the solid wastes generated by manufacturing industries. The absence of appropriate policy, lack of awareness and information, inadequate guidelines, limited time, lack of cooperation and application of old technologies such as end of pipe approaches are the common obstructive factors towards practicing efficient waste minimization by industries.

The study was conducted to review and analyze the practical waste minimization methodologies and its characteristics based on the industrial activities. In addition the obstacles which hold up industries from practicing waste minimization efficiently were determined. Thus this study suggest the effective practices for improving waste minimization which suitable for manufacturing industries in Malaysia.
\end{abstract}

Key Words: Industrial activities, Industrial solid waste characteristics, waste minimization methodologies, preventive factors

\section{Introduction}

In terms of providing human's need, industrialization has played an important role .Industrial activities produce the products that are fundamental for human's survival. Moving to a greater emphasize suggests that industrial activities improve the human's lifestyle from rural to urbanization. However the deterioration of environment and natural resources are the consequences of many industrial activities (Gandhi et al., 2006). Due to the destructive effects of industrial activities on human's health and environmental concerns, environmental management within industrial operations are more required(Srivastava \& Srivastava, 2003). According to the definition of sustainable development, sustainable industrial activities should be efficient in usage of resources by replacing non-renewable materials with renewable materials and modify goods production and services with less negative effects on environment, therefore covering both society and economy. In addition sustainable industrial activities generate minimum wastes and pollution to reduce the impacts on human (Gertsakis \& Lewis, 2003; Staniskis \& Stasiskiene, 2005).

\section{Historical approaches of Malaysian Industrial activities}

Since the past four decades, manufacturing industries have played a fundamental role in helping Malaysia move toward greater economic growth (Mohamed, 2009). After Malaysian independency in 1957, a considerable improvement in industrialization was observed. Much earlier, rubber and palm oil were dominant industries in Malaysia (Brookfield et al., 1994). In the period of 1961 - 1965 several industrial activities showed other increasing trends such as : Textile ,Food and agricultural industries which ,as a consequence, boosted Malaysia's economy. Industrial diversification was enhanced from 1965 to 1980 with a focus on technology and human resource development. This growth promoted apparel, furniture, plastic, food \&beverage and petroleum based products.

Since 1990 until the present, advanced improvements have been observed in electrical and electronic industries (Mohamed, 2009) .Manufacturing industries have done satisfactory and help increasing GDP to 5.2\% in 2005 (Malaysia, 2001). However in 2007 the global financial crisis, negatively affected the global economy which last until 2009. Before this crisis, Malaysia had benefited 10 years of economic growth. Over the first nine months of 2009, manufacturing continued to be a crucial sector of the Malaysian economy .But in the view of the economic burden with the rapid worsening of the global economic problem, the economy of Malaysia fell by 3.8 percent during the first three months of 2009 that led to the GDP contribution of $26 \%$ (Malaysia, 2009). Based on the Malaysia international trade and industry report in 2010 the manufacturing industry contribution was $27 \%$ of real GDP. The production index increased to 112.2 due to increase in domestic and external demand which expanded sales value by $13.8 \%$ to RM 534.4 billion (Malaysia, 2010). Results of Malaysian's investment activities in 2012 implies that despite negative growth in 2009 , the country has been successful in achieving its objectives .In 2012 manufacturing sectors bringing $24.9 \%$ to GDP and the exports of manufacturing declined to 
$0.1 \%$ compared with 2011(Malaysia, 2012). The following Figure (1), as below, compare the exports of products of different manufacturing sectors by 2012.

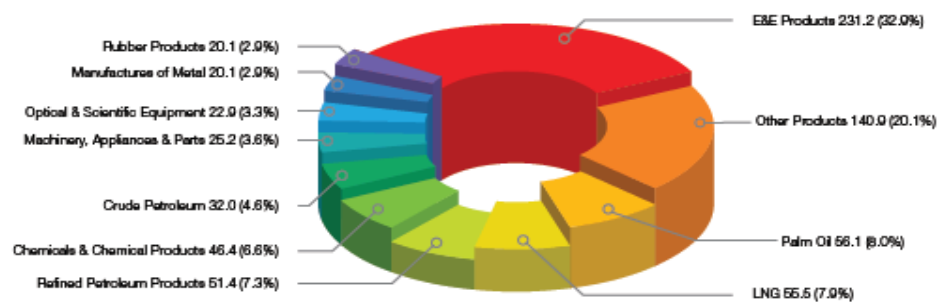

Fig.1: Top 10 exports by products ,2012 (MITI, 2012)

\subsection{Industrial classification and activities in Malaysia}

According to the ministry of Trade and Industry (MITI) reports in 2012, manufacturing sectors divided into non-resource based industries such as electrical and electronic, medical devices, textile and apparel, basic metal and machinery and equipment (transport equipment) industries. Beside that source-based industries including petrochemicals, pharmaceuticals ,wood based ,rubber based ,oil palm-based and the food processing industry (MITI, 2010).The following table (1) are the classifications that introduce the profile of industries and their sub- categories in Malaysia (FMM, 2011; MATRADE, 2013; MIDA, 2013; MITI, 2010).

\subsection{Industrial solid waste characteristics}

Establishing an efficient waste management system for industries cannot be achieved without providing the detailed information in terms of the volume of waste, its origin, composition and characteristics. The composition and characteristics of industrial solid wastes is varied and depending on the type of industrial activities. However, there is limited data on industrial solid waste composition and characteristics because many of industrial sectors are not willing to provide this information. (Nasir \& Chong, 2001)

According to US-EPA, Industrial wastes are classified in to hazardous industrial wastes and industrial solid nonhazardous wastes. The second category including any refuse and garbage from waste treatment plan and materials from industrial ,commercial, mining and agricultural activities, such as metals, cardboard and empty bottle (USEPA, 1998).

Industrial wastes in Malaysia classified into two groups as follows:

- Hazardous industrial wastes: These types of wastes known as schedule wastes are comprised by different component of wastes with toxic characteristics. The Department of Environment (DOE) is responsible for

managing these types of wastes under the Environmental Quality (Scheduled wastes) Regulation 1989.

- General solid wastes include; any non-hazardous solid waste that are generated within the manufacturing process. Local Government Act 1976, Street, Drainage and Building Act 1974 and Town and Country Planning Act 1974 are responsible for managing solid wastes (Mohamed, 2009).

Table 1: Description of industrial activities and types in Malaysia

\begin{tabular}{|c|c|c|c|}
\hline Type & PRODUCTS & Description & Solid waste \\
\hline $\begin{array}{l}\text { Medical device } \\
\text { industry }\end{array}$ & $\begin{array}{l}\text { Dominated products are Medical gloves, } \\
\text { Medical disposable products, Medical and } \\
\text { surgical equipment, instrument and appliances } \\
\text { for measuring and checking. }\end{array}$ & $\begin{array}{l}\text { Most of the Medical device manufacturing } \\
\text { in Malaysia are self-regulated and contain } \\
\text { the main multinational corporations with } \\
\text { high value products }\end{array}$ & $\begin{array}{l}\text { cardboard, glass } \\
\text { and plastic }\end{array}$ \\
\hline $\begin{array}{c}\text { Textile and } \\
\text { apparel industry }\end{array}$ & $\begin{array}{l}\text { It divided in to } 4 \text { major sub-sectors such as : } \\
\text { Primary textile, made up garments ,made-up } \\
\text { textile and textile ,textile accessories }\end{array}$ & $\begin{array}{l}\text { Textile manufacturing in Malaysia was the } \\
10^{\text {th }} \text { exporter in } 2011 \text { that cover } 2.3 \% \text { of } \\
\text { the whole Malaysian export of goods. }\end{array}$ & Textile, paper \\
\hline $\begin{array}{l}\text { Chemical } \\
\text { industry }\end{array}$ & $\begin{array}{l}\text { It categorized in to three main sub-categories } \\
\text { include chemicals and chemical products, } \\
\text { Plastic products, Pharmaceutical products and } \\
\text { Petroleum and petrochemical products. }\end{array}$ & $\begin{array}{l}\text { Chemical manufacturing is one of the } \\
\text { leading industries in Malaysia and located } \\
\text { at the second position of the largest exports } \\
\text { of goods }\end{array}$ & $\begin{array}{l}\text { Metal, glass, } \\
\text { wood, paper } \\
\text {,plastic and } \\
\text { cardboard }\end{array}$ \\
\hline $\begin{array}{l}\text { Machinery and } \\
\text { equipment } \\
\text { industry }\end{array}$ & $\begin{array}{l}\text { Contain the categories include Power } \\
\text { generating machinery and equipment ,metal } \\
\text { working machinery ,specialized process } \\
\text { machinery or equipment for specific industry } \\
\text { general industrial machinery \& equipment } \\
\text { component and parts }\end{array}$ & $\begin{array}{c}\text { Machinery and equipment industry play a } \\
\text { major role in economic growth and } \\
\text { development }\end{array}$ & Paper, metal \\
\hline $\begin{array}{l}\text { Wood based } \\
\text { industry }\end{array}$ & $\begin{array}{l}\text { This industrial activity comprise by three main } \\
\text { sub-categories include Furniture and furniture } \\
\text { components, Molding and builders' joinery } \\
\text { carpentry and sawn timber, veneer and panel } \\
\text { products }\end{array}$ & $\begin{array}{l}\text { In Malaysia approximately } 90 \% \text { of Wood } \\
\text { industries are contained in (SME) } \\
\text { establishment }\end{array}$ & Wood,paper \\
\hline Rubber-based & This industrial sectors breakdown in to the & Rubber-based manufacturing contain & Paper ,cardboard, \\
\hline
\end{tabular}




\begin{tabular}{|c|c|c|c|}
\hline industries & $\begin{array}{l}\text { three following items: } \\
\text { Latex products, tires and tire-related products, } \\
\text { industrial and general Rubber products }\end{array}$ & $\begin{array}{l}3.9 \% \text { of Malaysian total exports that } \\
\text { contribute } 18 \text { billion of the country export } \\
\text { in } 2011 \text {. }\end{array}$ & $\begin{array}{l}\text { plastic and rubber } \\
\text { wastes }\end{array}$ \\
\hline $\begin{array}{l}\text { Electrical and } \\
\text { electronic } \\
\text { industry }\end{array}$ & $\begin{array}{l}\text { There are four sectors under the Electrical and } \\
\text { Electronic industry such as : Electronic } \\
\text { component ,consumer electronics, industrial } \\
\text { electronics and electrical products }\end{array}$ & $\begin{array}{l}\text { This industry is known as the key sector in } \\
\text { economic and development growth in } \\
\text { Malaysia }\end{array}$ & $\begin{array}{l}\text { Plastic ,Paper, } \\
\text { steel, glass, scrap } \\
\text { metal, cardboard } \\
\text { and wood }\end{array}$ \\
\hline Food industry & $\begin{array}{l}\text { The main sub categories of Food industry in } \\
\text { Malaysia is :Fish and Fish products, livestock } \\
\text { and livestock products ,fruits \& vegetables and } \\
\text { cocoa. }\end{array}$ & $\begin{array}{l}\text { Food industries have the wide range of } \\
\text { products that is suitable for all Asian } \\
\text { tastes. In addition HALAL food industry } \\
\text { provide immune food products in } \\
\text { Malaysia. }\end{array}$ & $\begin{array}{l}\text { Paper, cardboard } \\
\text { and plastic }\end{array}$ \\
\hline $\begin{array}{l}\text { Basic metal } \\
\text { industry }\end{array}$ & $\begin{array}{l}\text { Basic metal products comprised by two major } \\
\text { sub-sectors include :Iron and Steel and non- } \\
\text { ferrous metal }\end{array}$ & $\begin{array}{l}\text { Metal manufacturing in Malaysia shows } \\
\text { the significant improvement within three } \\
\text { decades. }\end{array}$ & $\begin{array}{l}\text { Metal(iron, } \\
\text { copper, } \\
\text { aluminum),box } \\
\text {,glass ,paper and } \\
\text { plastic }\end{array}$ \\
\hline $\begin{array}{c}\text { Non-metallic } \\
\text { mineral industry }\end{array}$ & $\begin{array}{l}\text { Ceramic and clay-based product, Cement and } \\
\text { concrete products ,glass ,quick lime ,barite , } \\
\text { marble and granite }\end{array}$ & $\begin{array}{l}\text { It was reported ,non-metallic mineral } \\
\text { industry in Malaysia was one of the largest } \\
\text { exporting sectors in } 2011 \text { that was } \\
\text { contained } 1.2 \% \text { of the total exports }\end{array}$ & $\begin{array}{c}\text { glass, wood, } \\
\text { paper \& } \\
\text { cardboard, metal }\end{array}$ \\
\hline
\end{tabular}

Source : (Fariz, 2008; MATRADE, 2013; MIDA, 2011, 2012, 2013; MITI, 2010; Nasir \& Chong, 2001)

\subsubsection{Industrial solid waste quantity}

Asian countries generated approximately 19 million tons of industrial wastes in 2000 (Hotta, 2007). In Singapore, waste generation faced a decreasing trend because of waste minimization and recycling Activities. In terms of the household waste generation in Singapore, approximately 7700 tons of waste was generated daily in 2001 and decreased to about 7000 tons in 2007(Kojima \& Damanhuri, 2009).

Developing countries such as Malaysia ,Indonesia ,Thailand and Philippines have been experiencing an increasing trend of waste generation rate by almost $0.3 \mathrm{~kg} / \mathrm{cap}$ (Ngoc \& Schnitzer, 2009). For instance, Taiwan and Thailand are two countries with higher pollution load to the environment and have been facing the similar trend of industrial wastes by generating 18 million tons of industrial waste each year (Phechpakdee, 2009; Pratt \& Phillips, 2000; Wei \& Huang, 2001).

In 1992 solid wastes was recognized as the main environmental crisis in Malaysia (Desa et al., 2011). According to the statistics from the ministry of Housing and Local Government, the approximate amount of solid waste generated in whole Malaysia was 18000 Metric tons each day (Lee, 2007). In 1997 the quantity of wastes was about 2800 tons daily which reached a total approximate amount of 5,475000 tons in 2001 which was lower quantity of waste generated than in the UK with about $2.2 \mathrm{~kg} / \mathrm{cap} / \mathrm{day}$ and in Europe generated at 1.5 $\mathrm{kg} / \mathrm{cap} / \mathrm{day}$ (Ngoc \& Schnitzer, 2009). The amount of waste generated in Malaysia envisaged to reach more than 3000 tons per day by 2017 (Hotta, 2007).

In 1998, Industrial wastes consisted of $30 \%$ of total solid wastes which increased by $4 \%$ each year (Fariz, 2008).

In 2004, almost 8 million tons of wastes generated and approximately 2 million tons of this amount was related to business entities(Agamuthu et al., 2004; EA, 2009).Based on more recent years solid wastes generated from both industrial and household sectors in the capital of Malaysia was 3500 metric tons each day (Jalil, 2010) . According to the Lee (2007) report, solid wastes generated by industrial activities are no longer under the responsibility of most Local Authorities in Malaysia. Apart from that, there are no accurate figures for the amount of solid wastes that collected, transferred and disposed illegally .Existing figures regarding the quantity of industrial solid wastes generated include the portion of solid wastes that are recyclable, but for other wastes it is not counted. Hassan et al. (2001) estimated more than $30 \%$ of solid waste generation can be considered as recyclable wastes in Malaysia.(Hassan et al., 2001)

\subsubsection{Industrial Solid Waste Composition}

In some of the developing countries such as Thailand, Philippine and Malaysia, the composition of solid wastes may include: paper, plastic, packaging and bulky wastes with increasing trend toward waste generation (Ngoc \& Schnitzer, 2009). Paper, cardboard boxes, plastic and glass were the main solid wastes generates by manufacturing industries in Thailand (Muttamara et al., 1994). Based on the report of Department of Industrial Work in Thailand in 2007, there was approximately 16 million tons of non-hazardous industrial wastes out from about 18 million tons of total industrial wastes with the recovery potential (Mixture of hazardous and non-hazardous ). About $31 \%$ of iron , $24.54 \%$ of plastic and $25 \%$ of paper was estimated as the composition of industrial solid wastes in 2007 in Thailand (Phechpakdee, 2009). In Taiwan 14 industrial wastes were determined under the EPA that categorized into metallic industrial wastes, non-metallic industrial wastes and food processing wastes (Wei \& Huang, 2001). Organic wastes formed a considerable part of solid wastes in 
Malaysia with very high moisture. The dominant solid waste is related to (55\%) of food wastes and, almost $13 \%$ of paper and $19 \%$ of plastic wastes which contain $80 \%$ of the total solid wastes weight (Agamuthu \& Fauziah, 2011; Manaf et al., 2009). However China generates a lower quantity of paper wastes. The Figure ( 2 ) compare the percentage of solid waste generation in some Asian countries by 2000 (Agamuthu et al., 2007). The solid wastes send to land fill sites for disposal in Malaysia are the mixture of industrial and municipal solid wastes which include plastic, iron, paper, food wastes, rubber, textile, metal, glass, cardboard ,aluminum and miscellaneous (Agamuthu \& Fauziah, 2011; Desa et al., 2011; Saeed et al., 2009).

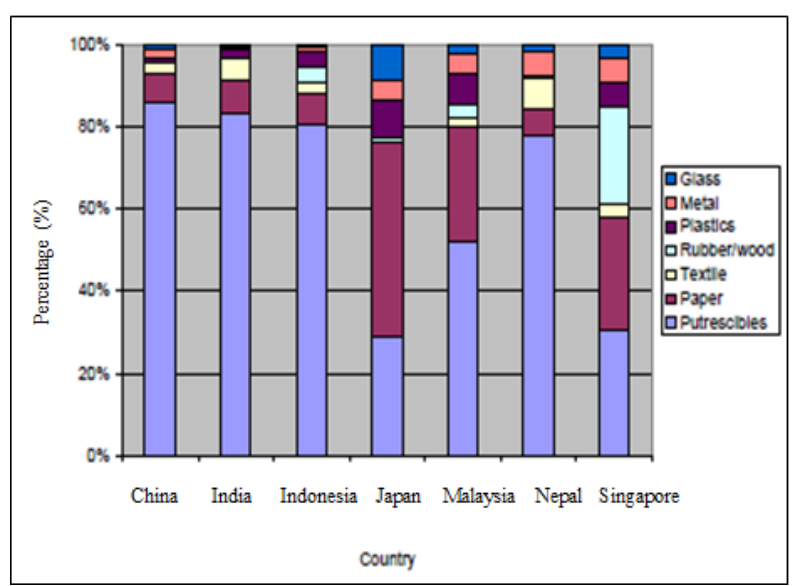

Fig.2: Solid waste generation (\%) by Asian countries

(Agamuthu et al., 2007)

General solid wastes in Malaysia play an important role in recycling markets by considering their economic value as mentioned in the following types (MHLG, 2005):

\section{i. Paper and Cardboard}

Paper has the most rapidly growing recycling market which has different types of impurities and values (Koroneos \& Nanaki, 2012). American Forest \& Paper Association reported almost 60\% of paper wastes recovered in 2011 instead of sending for disposal, however the recovery rate for plastic ,metal and glass was between almost 7 to 35 percent in 2009 (Mills \& Pearson, 2013).From the standpoint of environmental view for producing paper, natural resources required such as land, energy and trees .It was declared that about 17 trees survived by recycling papers .Beside that, lands for both disposal and wood producing will be saved (Mills \& Pearson, 2013)

Because of the increasing rate of raw wood pulp price, recycling of paper is required more in Malaysia. Malaysian News print Industries (MNI) and Genting Sanyen Industrial Paper (GSP) are two major industries that use recyclable paper for their process (MHLG, 2005). Source separation is done for some types of paper based on their market value (MHLG, 2006) .

\section{ii. Glass}

Glass products have many variations. This makes glass recycling a broad area (Moser, 2012) . Due to the high costs of raw materials in glass manufacturing industries, recycled glass is now needed more in Malaysia .However, some disadvantages remain by using recyclable glass due to the refusal rate (MHLG, 2005).

\section{iii. $\quad$ Plastic}

Due to the vast Plastic use, plastic waste creates major environmental issues considering its undegradable components. Plastic recycling is a helpful method for reducing its harmful effects (Gunarathna et al., 2012).Segregation of plastics is very challenging because of insufficient practicing of labeling. In Malaysia raw materials for plastic production is not too expensive ,so there is no motivation for using recycled plastics (MHLG, 2005)

\section{iv. Aluminum cans}

Recycling the Aluminum provides both cost saving and helps decrease harmful impacts on the environment .But the initial situation of raw material makes aluminum recycling more difficult (Duan et al., 2013). Using recyclable aluminum cans as a raw material for manufacturing is cheaper than raw materials, so it has cost saving benefits for the industries in Malaysia (MHLG, 2005).

\section{v. Metal wastes}


In Malaysia the quantity of metal wastes generated is little in comparison with other recyclable wastes .Due to the time consuming process of separating different types of metal, recycling metal is less required (MHLG, 2005).On the other hand recycling metal has some advantages including protecting natural sources by recovering mineral from wastes and saving the energy (Raghupathy \& Chaturvedi, 2013).

\section{vi. Organic wastes}

Composting is recognized as one treatment method for reducing the organic wastes from industrial and agricultural activities by using degradable microbes for wastes digestion. There are some effective factors for improving the quality of compost such as: moisture, temperature and oxygen content, and also the ratio of $\mathrm{C}$ and $\mathrm{N}$ within the composting process (Makan et al., 2012). Due to the odor and also difficulties in implementation involved in composting technologies, composting activities are not applied in large scale in Malaysia. Also In Malaysia there are not any legal or encouraging instrument for composting and energy recovering (MHLG, 2005, 2006).

\section{Prioritization in the Waste Management Hierarchy}

Waste minimization is defined as reduction of wastes at the point of generation with the perception of process due to wastes prevention and reduction. In addition waste minimization is recognized as replacement of materials into environmental friendly materials within the production. Waste minimization is given the highest priority in UK waste management hierarchy and is known as an essential method for any strategy of waste management .Re-use, recycling and composting, treatment and disposal is at the lower level of preference (McDougall et al., 2008; Phillips et al., 1999).

Recent research on waste management methods imply that landfilling the wastes has been reduced in many parts of the world. However, land fill disposal still remains as the main method of solid waste management in some industrialized countries including the UK, Australia and the US (Laner et al., 2012).

Babu et al. (2009) defined waste minimization as "the continuous application of a systematic approach to reducing the generation of waste at source". This definition contains source reduction and on-site recycling. By improving and changing available process and by applying an effective process, source reduction can be achieved

Waste minimization considered as the highest level of waste management hierarchy, it was known as the fundamental strategy of sustainable development (Phillips et al., 1999). Since 1992 ,waste minimization has been recognized as a fundamental component of industries and business entities in the U.K. and considerable decreasing of wastes in industrial sectors was achieved through the establishment of waste minimization clubs (Coskeran \& Phillips, 2005; Tonglet et al., 2004). In 1998 about 60 waste minimization clubs were recognized in the U.K. to explain the application of waste minimization as the most effective instruments in industrial and commercial wastes diminishing. Also, these clubs persuade industries to apply waste minimization methodologies (Phillips et al., 1999; Pratt \& Phillips, 2000). In Begum et al. (2007) waste minimization was defined as source reduction and recycling Source reduction includes any environmental exercises remove the waste at the point of generation, and recycling was explained as re-use or recovery of wastes .

\subsection{Benefits of practicing Waste Minimization by Industries}

In terms of waste minimization methods and practice there are some published debates. It emphasized that the type and the size of the industries play a key role in determining the proper technology and methodology of waste minimization (Babu et al., 2009; Begum et al., 2007; Maclaren, 2002; Vigneswaran et al., 1999).

In the U.K., waste minimization clubs play an important role in encouraging the industries for practicing waste minimization. Within the waste minimization clubs some policies have been recommend to industries. Some guidelines for practicing waste minimization by industries were provided by the U.K. Government. These guidelines played a key role in enhancing the awareness and the knowledge of waste minimization practices and passed it to Local Authorities. For instance it was suggested that methodologies for preventing wastes and improving the quality of generated wastes was a product modification, changing input material, changing technology, changing the procedures, good housekeeping, on site reuse /recycle and Offsite reuse and recycle(Phillips et al., 1999). Johnston (1995), revealed that pressure from the government, customers and the media, company image, cost saving ,environmental concerns and sustainable development, are the main reason of undertaking waste minimization practicing.

The adoption of waste minimization techniques in the food and drink industry in East of England is a main sector in the U.K ., leading to a considerable decrease amount of solid waste by 1370 tones and declined the consumption of material taken from natural resources, such as paper and packaging wastes, by 35 tons, reducing of operating costs, improved profitability and competitiveness, giving an improved company image at the local and international level, and stakeholder confidence (Bates \& Phillips, 1999; Poonprasit et al., 2005). In 
other study in U.K. it was revealed that the implementation of waste minimization projects at a high level with source efficiency was achieved in Putrescible wastage and packaging (Henningsson et al., 2004).

In Thailand, there are many ways for limiting waste arising that is achievable by waste minimization methodologies. Vigneswaran et al. (1999) introduced was some minimization methods and the emphasis was on the effectiveness of methodologies based on the type of industrial activity. These methodologies consisted of : "improved housekeeping, changing process technology, changing product, changing in put material, recycling process chemicals and raw materials, recovering by-product and reducing input to the process." Also, he mentioned that all minimization techniques can be effective in achieving sustainable waste management.

In Thailand paper and pulp industry play a vital role in economic growth, but it was reported that about 0.7 million tons of solid wastes produced each year. Process modifications and reuse techniques were implemented as methods of waste minimization to help decrease the amount of generated wastes (Chavalparit et al., 2006; Vigneswaran et al., 1999).

Rao and Prabhakar (2013) defined waste minimization as the considerable reduction of waste by implementing four strategies including :Source reduction, using recyclable material, good management and control practicing and waste segregation. These four methods have been introduced as an effective method of waste minimization in chemical industries. Staniskis and Stasiskiene (2005) analyzed the amount of wastes reduced in 12 types of industrial companies by applying waste minimization methodologies. Through waste minimization program $3 \%$ of wastes was reduced with good housekeeping, $25 \%$ of wastes reducing by technology modification, $52 \%$ of wastes reduced by applying process optimization, and $75 \%$ of wastes declined by on-site recycling .

Also some of waste minimization options and their efficiency were identified by Clelland et al. (2000) including methods of inventory control, raw material modification, product modification, production process modification, cleaning and degreasing, changing packaging and equipment modification.

According to Babu et al. (2009), methodologies such as: improved housekeeping, changing technological process ,changing product, changing input material, recycling chemicals and raw materials. It was indicated that recovering by-product and reducing input to process were the waste minimization method with good successful results in his study which was regarding the electroplating industrial wastes minimization.

The following Figure (3) illustrates the waste minimization component and methodologies (Begum et al., 2007). According to the figure waste reduction at the source and recycling are two main practices of waste minimization

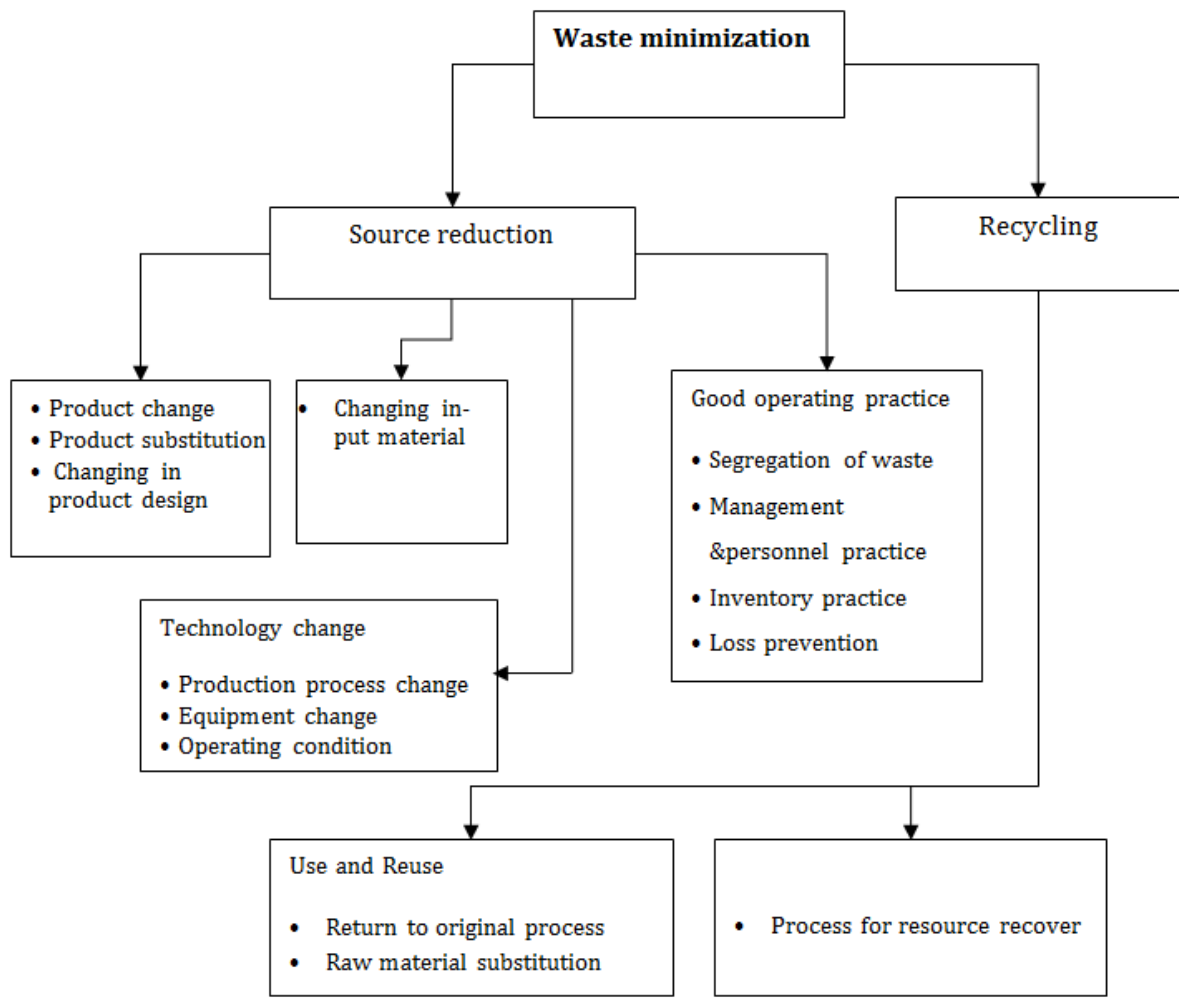

Fig .3 :Waste Minimization Conceptual Framework (Begum et al., 2007) 


\subsection{Waste Minimization practicing in Malaysia}

In Malaysia, landfill dumping is the most common option of waste management. Almost $95 \%$ of waste is sent to landfill sites and most of this is dumped in sites that are open areas without proper control .For industrial waste management in Malaysia greater priority is given to end of pipe approaches than waste minimization and recycling. Rampant evidence of illegal waste disposal and lack of land implies the inefficiency of industrial waste management methods. As an example of illegal dumping sites it was reported that approximately 50 illegal dumping sites existed in Klang valley with the capacity of almost 100 tons of wastes(Agamuthu \& Fauziah, 2011; Mohamed, 2009; Yunus \& Kadir, 2003).

To accomplish the waste minimization's target in Malaysia, the hierarchy requires to be changed to practice to $22 \%$ of recycling and less landfill by 2020 which was specified about $14 \%$ for recycling of Municipal ,Commercial and Industrial wastes and 30\% for recycling of construction wastes. Fig (4), compares the current and the targeted condition of waste management hierarchy (EA, 2009; MHLG, 2005).

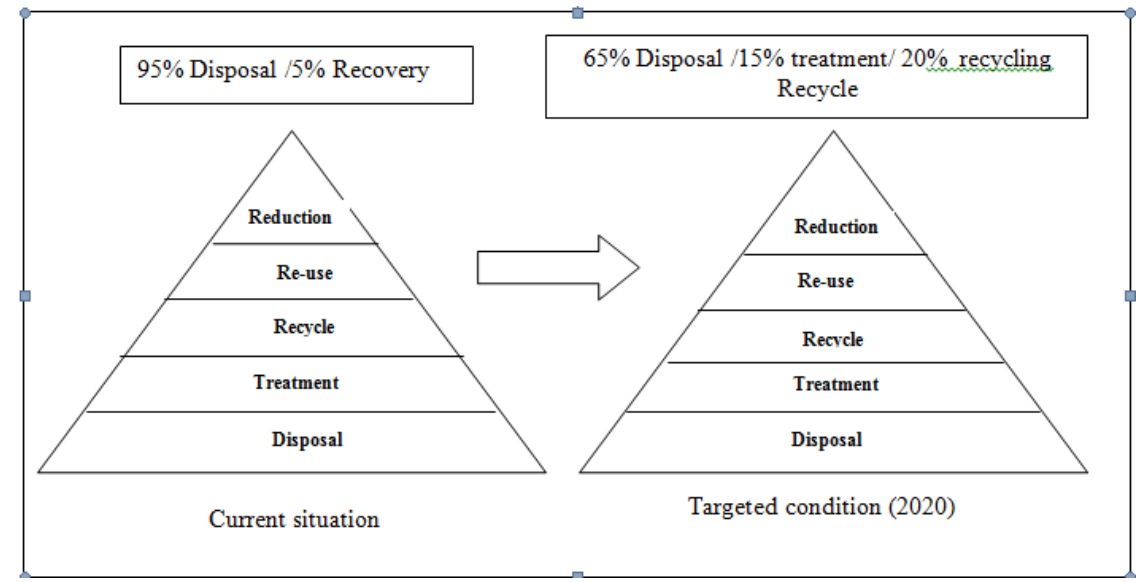

Fig .4: Malaysian current and targeted waste hierarchy by 2020 (EA, 2009)

It was reported in Malaysia, practicing waste minimization by industries is not very common and just a few number of industries apply waste minimization as one component in waste management hierarchy, so this number is not great enough to reduce the total quantity of generated waste (MHLG, 2005)

In 2005 the Ministry of Housing and Local Government in Malaysia (MHLG) introduced some effective practices to achieve waste reduction by industrial sectors including (MHLG, 2005) :

- Enhancing the quality of input material due to decreasing the unwanted wastes within the process

- Modification of production process due to minimize the wastes

- Reusing of rejected wasted material from the process as a source material

- Decreasing the packaging usage

\section{Barriers in Practicing Waste Minimization}

Despite the developed countries, implementation of 3R strategy to minimize the quantity of wastes is not effective enough because of some barriers(Pariatamby \& Fauziah, 2014).

Previous studies have proven that issues regarding practicing waste minimization are common among industrial sectors. A lack of awareness, knowledge and information, inappropriate packaging, lack of time, old technologies and incapability in implementation of institutional, governance and economic factors and old technologies are the prevalent obstacles of practicing waste minimization by industrial sectors.(EA, 2009; Goh, 1990; Isa et al., 2005; Pariatamby \& Fauziah, 2014; Perdue, 2011; Pongrácz, 2009; Poonprasit et al., 2005) .

\section{i. Awareness and knowledge issues:}

Analyzing the results from Chenayah et al. (2007), demonstrated that awareness plays an effective role in recycling activities. It was further noted that environmental knowledge plays a fundamental role in forming waste management behavior (Barr, 2007).

Pongrácz (2009) in his study on barriers of waste minimization in Finland stated that poor attitudes of personnel, technology deficiency, Lack of trained personnel and knowledge provision by the authorities were realized as obstacles in food and drink industries which when coupled with the high demand of packaging cause a considerable amount of waste generated. According to the study was done by Desa et al. (2011) on the " assessment of knowledge, attitudes, awareness, behavior and practice concerning solid waste management", respondents implied that the government was responsible for achievement of sustainable waste management. 
Also it was suggested that campaigning for awareness played an effective role in enhancing the awareness and helps change attitudes and perception toward solid waste management (Desa et al., 2011).

\section{ii. Technology issues}

Research results considered technology as a barrier in waste management in Asian countries (Agamuthu et al., 2007; Babu et al., 2009; Phillips et al., 1999).Ilomäki and Melanen (2001) in his analyses of waste minimization in small and medium enterprises, revealed that technology is an efficient tool which offers a great opportunity in waste minimization.

\section{iii. Governance issues :}

Moving toward greater emphasis in developing countries, some common issues can be seen regarding ineffectual government monitoring and solid wastes management laws. Ineffective enforcement is preventive factor in implementation of 3R strategy for minimizing the waste(Agamuthu et al., 2007; Pariatamby \& Fauziah, 2014).

Manaf et al. (2009) revealed that inadequate facilities for wastes collection and the absence of expertise beside insufficient regulations are the barriers in waste management.

Another conducted study revealed lack of dynamic partnership between industries and Local Authorities were considered a hindering factor for efficient reduction of wastes and sustainable development principles (Phillips et al., 1999). Pongrácz (2009), introduced a regulatory framework as an effective instrument in controlling waste arising, alsoNgoc and Schnitzer (2009) debate regarding the lack of regulatory framework implied that in many Asian countries waste management statutes do not enforce severely enough . Additionally, the absence of appropriate guideline in factories may prevent manufactures from recognizing their chances for improving their activities regarding sustainable development targets (Smith \& Ball, 2012) .

\section{iv. Other issues :}

The weakness in packaging of products may affect waste minimization practices such as using non-recyclable material and inefficient managing of packaging (Henningsson et al., 2004; Poonprasit et al., 2005).

It may also be considered that the absence of time is a preventive factors in perception of waste management (Tonglet et al., 2004) .In other research, the lack of time hampers the effective implementation of regulations enforcement (Goh, 1990) .It was further noted that fiscal aspects played a fundamental role in waste minimization implementation and the absences of financial support is a fundamental barrier in wastes management (Agamuthu \& Fauziah, 2011).Following an appropriate practice of waste minimization ,cost saving by any company can be achieved (Bates \& Phillips, 1999).

\section{Conclusions}

considering the Malaysia's target to be an industrialized country by 2020 and ensuring sustainable development, it should be emphasized that industries must implement sustainable practice by giving more priority for reduction and prevention of waste than treatment and disposal in the waste management hierarchy (Phillips et al., 1999; Pratt \& Phillips, 2000). Dealing with waste management problems and finding appropriate solutions to those problems are necessary to realizing the limitations faced when implementing waste minimization practices.

Obstacles of practicing waste minimization by industries in Malaysia are the same some other countries, Research evidence in Malaysia revealed that, limited information, lack of basic data and inappropriate system for data collection, industrial waste generation and composition, conflicts in solid waste definition are some of the most fundamental barriers for planning suitable waste management (MHLG, 2005, 2006).

Absence of environmental awareness and perception can affect waste minimization practicing. Besides that, the absence of expertise which can provide the knowledge technically making the situation of waste management worse (Agamuthu et al., 2007; EA, 2009). According to the MHLG report in 2006 awareness issues should be taken as very important issue that required serious action and attention (MHLG, 2006).

Raising awareness and training of staff who manage and handle the wastes can be very effective in implementing the necessary first step toward the minimization of wastes at the point of generation. And in more recent years, small numbers of industrial sectors have applied the segregation of solid wastes at the source for the goal of on- site recycling as one method of waste minimization (Babu et al., 2009). A move toward a greater emphasis, reduction, reuse and recycling activities in Malaysia is mainly affected by knowledge and awareness (Agamuthu \& Fauziah, 2011). Therefore organizing workshops and campaigns under the supervision of knowledgeable institutions such as agencies is effective in dealing with above issues.

In Malaysia, the Ministry of Housing and Local Government, the Ministry of Education, the Ministry of Natural Resources and Environment and Economic Planning Unit all arrange workshops and campaigns. 
These workshops introduce the principles of waste management and waste generation to the public and stakeholders and help them improve recycling activities (Agamuthu \& Fauziah, 2011).

An absence of sufficient funds and time have hampered the Local Authorities to provide data and information that create specific problems of wastes management (EA, 2009).From the fiscal point of view, there is not specified fund that may provide for industrial segments to reduce their wastes (MHLG, 2005)

To accomplish the targets of waste management hierarchy of priorities, institutional factors may play a fundamental role. As past experiences have proven that absence of appropriate policies and regulations as well as weaknesses in implementation and monitoring often creates many issues regarding waste management. Illegal dumping in Malaysia is one of the most important challenges in waste management that can be affected by the attitude among waste collectors and insufficient regulations .(Agamuthu \& Fauziah, 2011) .Considering the lack of regulatory framework in Malaysia, the control of the quantity of generated waste is not possible (MHLG, 2005). Effective and efficient implementation of regulatory measures and enforcement of regulatory related matters are hugely necessary in order to solve future preventive issues in waste minimization practices.

\section{Reference}

[1]. Agamuthu, P., \& Fauziah, S. (2011). Challenges and issues in moving towards sustainable landfilling in a transitory countryMalaysia. Waste Management \& Research, 29(1), 13-19. doi: 10.1177/0734242X10383080

[2]. Agamuthu, P., Fauziah, S., Khidzir, K., \& Aiza, A. N. (2007). Sustainable waste management-Asian perspectives. Paper presented at the Proceedings of the International Conference on Sustainable Solid Waste Management. 5.

[3]. Agamuthu, P., Fauziah, S. H., \& C, S. (2004). Toward efficient waste management in a developing countries (Malaysia)-the dilemma. Philadelphia,USA.

[4]. Babu, B. R., Bhanu, S. U., \& Meera, K. S. (2009). Waste minimization in electroplating industries: a review. Journal of Environmental Science and Health Part C, 27(3), 155-177. doi: 10.1080/10590500903124158

[5]. Bates, M. P., \& Phillips, P. S. (1999). Sustainable waste management in the food and drink industry. British Food Journal, 101(8), 580-589. doi: 10.1108/00070709910288270

[6]. Begum, R. A., Siwar, C., Pereira, J. J., \& Jaafar, A. H. (2007). Implementation of waste management and minimisation in the construction industry of Malaysia. Resources, Conservation and Recycling, 51(1), 190-202.

[7]. Brookfield, H. C., Doube, L., \& Banks, B. (1994). Transformation with industrialization in peninsular Malaysia: Oxford University Press, USA.

[8]. Chavalparit, O., Rulkens, W., Mol, A., \& Khaodhair, S. (2006). Options for environmental sustainability of the crude palm oil industry in Thailand through enhancement of industrial ecosystems. Environment, Development and Sustainability, 8(2), $271-287$.

[9]. Chenayah, S., Takeda, E., \& Agamuthu, P. (2007). Multicriteria modelling on recycling of municipal solid waste in Subang Jaya. Malaysian Journal of Science, 26(1), 1-16.

[10]. Clelland, I. J., Dean, T. J., \& Douglas, T. J. (2000). Stepping towards sustainable business: An evaluation of waste minimization practices in US manufacturing. Interfaces, 30(3), 107-124.

[11]. Coskeran, T., \& Phillips, P. S. (2005). Economic appraisal and evaluation of UK waste minimisation clubs: proposals to inform the design of sustainable clubs. Resources, Conservation and Recycling, 43(4), 361-374.

[12]. Desa, A., Kadir, N. B. y. A., \& Yusooff, F. (2011). A Study on the Knowledge, Attitudes, Awareness Status and Behaviour Concerning Solid Waste Management. Procedia-Social and Behavioral Sciences, 18, 643-648. doi: 10.1016/j.sbspro.2011.05.095

[13]. Duan, R. B., Bai, P. K., Yang, J., Zhang, W. D., \& Ding, H. (2013). Study on Waste Aluminum Cans Remelting and Purification Technology. Applied Mechanics and Materials, 372, 360-363.

[14]. EA. (2009). Perak-Solid Waste Management Plan (P-SWMP),EA-SWMC,EU-Asia Sustainable waste management Cycle,.

[15]. Fariz, M. (2008). Infrastructure for Sustainable Industrial Wastes Recovery in Malaysia Paper presented at the Blueprints for Sustainable Infrastructure Conference, Auckland, NZ.

[16]. FMM. (2011). Malaysian Industries.

[17]. Gandhi, N. M. D., Selladurai, V., \& Santhi, P. (2006). Unsustainable development to sustainable development: a conceptual model. Management of environmental quality: an international journal, 17(6), 654-672.

[18]. Gertsakis, J., \& Lewis, H. (2003). Sustainability and the waste management hierarchy. Retrieved on January, 30, 2008.

[19]. Goh, K. S. (1990). Developing hazardous waste programmes in Malaysia. Waste Management \& Research, 8(2), 151-156.

[20]. Gunarathna, G., Bandara, N., \& Liyanage, S. (2012). Analysis of Issues and Constraints Associated with Plastic Recycling Industry in Sri Lanka. Paper presented at the Proceedings of International Forestry and Environment Symposium.

[21]. Hassan, M. N., Theng, L. C., Rahman, M., Salleh, M. N., Zakaria, Z., \& Awang, M. (2001). Solid waste management-what's the Malaysian position. Malaysian Journal of Environmental Management, 2, 25-43.

[22]. Henningsson, S., Hyde, K., Smith, A., \& Campbell, M. (2004). The value of resource efficiency in the food industry: a waste minimisation project in East Anglia, UK. Journal of Cleaner Production, 12(5), 505-512. doi: 10.1016/S0959-6526(03)00104-5

[23]. Hotta, Y. (2007). Internationalization of Waste and Recycling Problems - Towards

[24]. EPR Mechanism from International Perspective.Workshop on EPR and

[25]. International Material Flow, . Manila.

[26]. Ilomäki, M., \& Melanen, M. (2001). Waste minimisation in small and medium-sized enterprises-do environmental management systems help? Journal of Cleaner Production, 9(3), 209-217.

[27]. Isa, M. H., Asaari, F. A., Ramli, N. A., Ahmad, S., \& Siew, T. S. (2005). Solid waste collection and recycling in Nibong Tebal, Penang, Malaysia: a case study. Waste Management \& Research, 23(6), 565-570. doi: 10.1177/0734242X05059803

[28]. Jalil, M. A. (2010). Sustainable development in Malaysia: A case study on household waste management. Journal of Sustainable Development, 3(3), P91.

[29]. Johnston, N. (1995). Waste Minimisation and cleaner technology: An assessment of motivation: Centre for Exploitation of Science and Technology.

[30]. Kojima, M., \& Damanhuri, E. (2009). 3R Policies for Southeast and East Asia. ERIA Research Project Report(10).

[31]. Koroneos, C. J., \& Nanaki, E. A. (2012). Integrated solid waste management and energy production-a life cycle assessment approach: the case study of the city of Thessaloniki. Journal of Cleaner Production, 27, 141-150. 
[32]. Laner, D., Crest, M., Scharff, H., Morris, J. W., \& Barlaz, M. A. (2012). A review of approaches for the long-term management of municipal solid waste landfills. Waste management, 32(3), 498-512.

[33]. Lee, G. B. (2007). Solid waste management :Issues and challenges in Asia (Environmental Managment Center,India ed., pp. 118). Japan.

[34]. Maclaren, V. (2002). Appropriate industrial waste management strategies for developing countries waste economy. http://www.utoronto.ca/env/vietpro/waste/Chapt5.htm

[35]. Makan, A., Assobhei, O., \& Mountadar, M. (2012). Effect of initial moisture content on the in-vessel composting under air pressure of organic fraction of municipal solid waste in Morocco. Iran J Environ Healt, 10(3).

[36]. Malaysia. (2001). Eighth Malaysia Plan 2001-2005. Putrajaya,Malaysia.

[37]. Malaysia. (2009). Performance of the manufacturing and services sectors.

[38]. Malaysia. (2010). Malaysia International Trade and Industry Report

[39]. Malaysia. (2012). Malaysia Investment Performance.

[40]. Manaf, L. A., Samah, M. A. A., \& Zukki, N. I. M. (2009). Municipal solid waste management in Malaysia: Practices and challenges. Waste management, 29(11), 2902-2906.

[41]. MATRADE. (2013). Chemical \& Chemical products Retrieved from www.matrade.gov.my

[42]. McDougall, F. R., White, P. R., Franke, M., \& Hindle, P. (2008). Integrated solid waste management: a life cycle inventory: Wiley. com

[43]. MHLG. (2005). National Strategic Plan for Solid Waste Management Malaysia

[44]. MHLG. (2006). The study on National Waste Minimization in Malaysia Malaysia

[45]. MIDA. (2011). Malayian Investment Performance.

[46]. MIDA. (2012). Malaysian Investment performance

[47]. MIDA. (2013). Malaysian Industries. Malaysia Retrieved from http://www.mida.gov.my.

[48]. Mills, R., \& Pearson, C. (2013). Recycling in Utah: Paper.

[49]. MITI. (2010). Third Industrial Master Plan (IMP3). Retrieved from www.miti.gov.my

[50]. MITI. (2012). Driving transformation powering growth Malaysia: Ministry Of International Trade and Industry

[51]. Mohamed, F. (2009). Institute for The Environment and Development (LESTARI) Universiti Kebangsaan Malaysia. 3R Policies for Southeast and East Asia, 53.

[52]. Moser, H. (2012). GLASS RECYCLING TECHNOLOGIES OF TODAY. Paper presented at the 72nd Conference on Glass Problems: Ceramic Engineering and Science Proceedings.

[53]. Muttamara, S., Visvanathan, C., \& Alwis, K. (1994). Solid waste recycling and reuse in Bangkok. Waste Management \& Research, 12(2), 151-163.

[54]. Nasir, M., \& Chong, T. L. (2001). study on solid waste generation rates Sarawak: Natural Research and Environmental Board.

[55]. Ngoc, U. N., \& Schnitzer, H. (2009). Sustainable solutions for solid waste management in Southeast Asian countries. Waste management, 29(6), 1982-1995.

[56]. Pariatamby, A., \& Fauziah, S. (2014). Sustainable 3R Practice in the Asia and Pacific Regions: The Challenges and Issues Municipal Solid Waste Management in Asia and the Pacific Islands (pp. 15-40): Springer.

[57]. Perdue, B. E. (2011). Hazardous waste compliance manual for generators of hazardous waste. North Carolina

[58]. Phechpakdee, P. (2009). 3R Policies for Southeast and East

[59]. Asia (pp. 161-181). Jakarta.

[60]. Phillips, P. S., Read, A. D., Green, A. E., \& Bates, M. P. (1999). UK waste minimisation clubs: a contribution to sustainable waste management. Resources, Conservation and Recycling, 27(3), 217-247.

[61]. Pongrácz, E. (2009). Through waste prevention towards corporate sustainability: analysis of the concept of waste and a review of attitudes towards waste prevention. Sustainable Development, 17(2), 92-101. doi: 10.1002/sd.402

[62]. Poonprasit, M., Phillips, P. S., Smith, A., Wirojanagud, W., \& Naseby, D. (2005). The application of waste minimisation to business management to improve environmental performance in the food and drink industry. Paper presented at the In: Procs of the 7th Finnish Conf on Environmental Science, Jyvaskyla 2005.

[63]. Pratt, R. M., \& Phillips, P. S. (2000). The role and success of UK waste minimisation clubs in the correction of market and information failures. Resources, Conservation and Recycling, 30(3), 201-219.

[64]. Raghupathy, L., \& Chaturvedi, A. (2013). Secondary resources and recycling in developing economies. Science of The Total Environment.

[65]. Rao, L. N., \& Prabhakar, G. (2013). Waste Minimization in the Chemical Process

[66]. Industries-A Review. Journal of Chemical, Biological and Physical Sciences, 3(2), 1594-1601.

[67]. Saeed, M. O., Hassan, M. N., \& Mujeebu, M. A. (2009). Assessment of municipal solid waste generation and recyclable materials potential in Kuala Lumpur, Malaysia. Waste management, 29(7), 2209-2213.

[68]. Smith, L., \& Ball, P. (2012). Steps towards sustainable manufacturing through modelling material, energy and waste flows. International Journal of Production Economics, 140(1), 227-238.

[69]. Srivastava, R., \& Srivastava, S. (2003). How Green are Indian Firms?

[70]. Staniskis, J. K., \& Stasiskiene, Z. (2005). Industrial waste minimization-experience from Lithuania. Waste Management \& Research, 23(4), 282-290.

[71]. Tonglet, M., Phillips, P. S., \& Bates, M. P. (2004). Determining the drivers for householder pro-environmental behaviour: waste minimisation compared to recycling. Resources, Conservation and Recycling, 42(1), 27-48.

[72]. US-EPA. (1998). Solid Waste Disposal in the United States (EPA/530-SW-88-011 ed., Vol. 1 and 2).

[73]. Vigneswaran, S., Jegatheesan, V., \& Visvanathan, C. (1999). Industrial waste minimization initiatives in Thailand: concepts, examples and pilot scale trials. Journal of Cleaner Production, 7(1), 43-47.

[74]. Wei, M.-S., \& Huang, K.-H. (2001). Recycling and reuse of industrial wastes in Taiwan. Waste management, 21(1), 93-97.

[75]. Yunus, M. N. M., \& Kadir, K. A. (2003). The development of solid waste treatment technology based on refuse derived fuel and biogasification integration. Paper presented at the International Symposium on Renewable Energy, Kuala Lumpur 